\title{
Multivariate accelerated shelf-life test of low fat UHT milk
}

\author{
Melanie Richards, Henriëtta L. De Kock, Elna M. Buys* \\ Department of Food Science, University of Pretoria, Pretoria, 0001, South Africa \\ melanie.richards@up.ac.za, riette.dekock@up.ac.za, elna.buys@up.ac.za \\ *Corresponding author: Tel: +27 12 4203209; E-mail address: elna.buys@up.ac.za
}

Real time shelf-life determination of shelf stable products like UHT milk can be very time consuming and expensive and critical attributes used to determine the end of shelf life can be difficult to identify. The multivariate accelerated shelf life test (MASLT) employs all sensory attributes that show change over time and was applied to data obtained from a trained panel $(n=11)$ that evaluated 18 sensory attributes of low fat UHT milk samples stored at 25,35 and $45^{\circ} \mathrm{C}$ over a six and a half month time period. The cut-off point that identifies the end of shelf life was obtained by survival analysis based on consumers' acceptance or rejection of samples stored for different times and at different temperatures. Storage at 35 and $45^{\circ} \mathrm{C}$ reduced the shelf life by a factor of 2.9 and 7.8, respectively. In future, changes in sensory attributes that correlate well with the UHT milk MASLT model can be used as predictors for end of shelf life. For this purpose the milk can be stored at accelerated temperatures and results can be converted to actual market condition.

\section{INTRODUCTION}

Consumers demand safe and nutritionally high-quality products with superior texture, appearance and flavour and shelf-lives of several weeks or months (Corrigan, Hedderley \& Harvey, 2012; Grunert, 2005; Hugas, Garriga, \& Monfort, 2002; Smith \& Sparks, 2004). Quality changes, rather than microbial safety, are the deciding factors in determining the shelf-life of shelf stable food products (Corrigan et al., 2012; Lewis \& Heppell, 2002). Conducting a complete shelf-life test for shelf stable products can be very resource and time consuming, with the result that accelerated shelf-life tests are often employed (Corrigan et al., 2012; Meeker \& Escobar, 1998). During accelerated tests, the product is subjected to relatively severe storage conditions where one or more accelerating factors (e.g. temperature, humidity and 
water activity) are maintained at a higher level than normal. The accelerating factor used depends on the product and its normal storage conditions. By subjecting the food to such a controlled environment, the deterioration rate will be increased, resulting in a shorter time to product failure. Examples of accelerated shelf-life tests include the use of increased temperature to accelerate the changes in human milk replacement formula (Curia \& Hough, 2009), fruit-filled snack bars (Corrigan et al., 2012) and tomato concentrate during storage (Pedro \& Ferreira, 2006) and the use of a combination of oxygen partial pressure, temperature and water activity during the storage of coffee (Cardelli \& Labuza, 2001). The results obtained from accelerated tests are extrapolated to obtain the shelf-life estimates at the normal storage conditions of the product (Meeker \& Escobar, 1998).

Ultra-high temperature (UHT) processed milk has a reported shelf-life of between 6 9 months at room temperature (Perkins, D’Arcy, Lisle, \& Deeth, 2005). Both the shelf-life and the acceptability of UHT milk is determined by its sensory properties (Badings, 1991). The sensory quality and therefore the shelf-life of UHT milk is governed by the progression of various physico-chemical and biochemical changes after processing. The main changes that occur upon storage of UHT milk are due to proteolytic, lipolytic, oxidative and Maillard type reactions (Datta \& Deeth, 2003). Although UHT processing inactivates most bacteria, some heat-stable enzymes of native and bacterial origin can survive this process and cause shelf-life limiting defects (Burton, 1988; Valero, Villamiel, Miralles, Sanz, Martínez-Castro, 2001). Proteolysis of UHT milk is associated with the release of tyrosine in the milk that may contribute to the development of off-flavours (Gebre-Egziabher, Humbert, \& Blankenagel, 1980), while the release of $\beta$-lactoglobulin- $\kappa$-casein complexes, formed during heat treatment, from the micelle and subsequent aggregation of these complexes results in an increase in viscosity, with the eventual formation of a gel (McMahon, 1996; Chen, Daniel, \& Coolbear, 2003; Datta \& Deeth, 2003). Lipases can hydrolyse triacylglycerols with the release of medium and short-chain fatty acids that give rise to soapy and tangy flavours, respectively. Free fatty acids released during lipolysis are also precursors for other flavour compounds responsible for the formation of off-flavours such as oxidised, cardboard, bitter, rancid, soapy, unclean and metallic (Deeth \& Fitz-Gerald, 1983; 1994). Oxidative and Maillard reactions can result in a cascade of reaction responsible for loss in nutrients and amino acids, 
discolouration of the milk and development of off-flavours (Burton, 1988; Borle, Sieber, \& Bosset, 2001; Hedegaard et al., 2006). Due to the long shelf-life of UHT milk and the various factors that can influence the shelf-life thereof, there is a need to design a model whereby the shelf-life of milk can be predicted in a short timeperiod. The first part of this study aimed to determine the shelf-life of a specific brand of low fat UHT milk in high-density polyethylene (HDPE) bottles by employing the multivariate accelerated shelf-life test (Pedro \& Ferreira, 2006) by using normal storage temperature $\left(25^{\circ} \mathrm{C}\right)$ and elevated temperatures $\left(35\right.$ and $45^{\circ} \mathrm{C}$ ) as accelerating factor and evaluating the changes in the sensory properties over time. The second part of the study aims to identify the attributes that can be used as predictors for the end of shelf-life by comparing the activation energies and acceleration factors of the attributes to those of the multivariate data.

\section{MATERIALS AND METHODS}

\subsection{Samples and sample preparation}

Milk from three different batches (3 replicates) of a specific brand of low fat UHT milk in HDPE bottles was collected on the day of production and stored at room temperature $\left(25^{\circ} \mathrm{C}\right)$, and elevated temperatures of 35 and $45^{\circ} \mathrm{C}$. These elevated storage temperatures served as accelerating factors to speed up the deterioration process in the milk. Different batches were collected approximately 1 month apart to ensure that panellists receive both deteriorated and fresh samples, thus preventing bias from panellists realizing they are participating in a shelf-life test. One bottle from each batch was used for analysis at the various sampling points. For the sensory evaluation, milk samples were chilled in a refrigerator at $7^{\circ} \mathrm{C}$ after portioning (50 $\mathrm{mL}$ ) and served at $15 \pm 1^{\circ} \mathrm{C}$ in 3-digit random coded glasses covered with foil. Panellists received numbered trays with samples served in an order determined by the Williams Latin Square design (Williams, 1949). Peeled, sliced fresh raw carrots and filtered water were provided for neutralising and cleansing the palate before and between sample tasting. General Good Sensory Practices (GSP's) (Lawless \& Heymann, 1998) were followed in the selection, preparation, and serving of samples to panellists. 


\subsection{Sensory evaluation of UHT milk}

Sensory evaluation of the UHT milk was performed by eleven trained sensory panellists ( 9 females and 2 males) that were selected based on their performance in screening tests which included recognition of basic tastes and discrimination between small flavour differences. As initial guidelines for this study, attributes, references and definitions from previous studies on milk were used (Bassette, Fung, \& Mantha, 1986; Chapman, Lawless, \& Boor, 2001; Claassen \& Lawless, 1992; Frandsen, Dijksterhuis, Brockhoff, Nielsen, \& Martens, 2003; Frost, Dijksterhuis, \& Martens, 2001). During six orientation sessions (2h each) panellists determined which attributes best describes the UHT milk and changed some attribute definitions and references, and removed those that they did not find relevant to the UHT milk samples. A total of 18 different attributes were generated to describe the aroma, flavour, appearance, texture and aftertaste of the low fat UHT milk (Table 1). The Feedback Calibration Method (FCM) gives immediate graphical computerized feedback after evaluation of

Table 1: References and definitions for attributes developed in the descriptive sensory evaluation of low fat UHT milk in HDPE bottles.

\begin{tabular}{|c|c|c|}
\hline Sensory attribute & Definition & Reference (10 point scale) \\
\hline \multicolumn{3}{|l|}{ Aroma } \\
\hline Cooked aroma & $\begin{array}{l}\text { Intensity of boiled milk aroma/ The combination of } \\
\text { brown flavour notes and aromatics associated with heated } \\
\text { milk. }\end{array}$ & $\begin{array}{l}\text { Heat fresh pasteurised milk to } \\
80^{\circ} \mathrm{C} \text { for } 1 \mathrm{~min}=1 \\
\text { Boil milk for } 3 \mathrm{~min}=8\end{array}$ \\
\hline Overall milk (dairy) aroma & $\begin{array}{l}\text { A general term for the aromatics associated with cow's } \\
\text { milk products. }\end{array}$ & Fresh cream $=10$ \\
\hline Fresh milk aroma & The basic aromatic of fresh milk. & $\begin{array}{l}\text { Fresh low fat pasteurized milk }= \\
10\end{array}$ \\
\hline \multicolumn{3}{|l|}{ Appearance } \\
\hline Glass coating & $\begin{array}{l}\text { Extent to which milk cling to the inner surface of the } \\
\text { serving glass after swirling the sample }\end{array}$ & $\begin{array}{l}\text { Cream }=10 \\
20 \% \text { water in low fat milk }=1\end{array}$ \\
\hline Extent of visual thickness & Degree of thickness measured during swirling of glass & Cream $=10$ \\
\hline \multicolumn{3}{|l|}{ Texture } \\
\hline Viscosity & $\begin{array}{l}\text { The measure of the flow as the milk moves over the } \\
\text { tongue. }\end{array}$ & $\begin{array}{l}\text { Water }=0 \\
\text { Cream }=10\end{array}$ \\
\hline Fat feel & $\begin{array}{l}\text { The measure of the perceived fat content of the milk and } \\
\text { the intensity of the oily feeling in the mouth when the } \\
\text { milk is manipulated between the tongue and the palate. }\end{array}$ & Cream $=10$ \\
\hline Mouth coating & $\begin{array}{l}\text { The extent to which milk cling to the inner surface of } \\
\text { the mouth. }\end{array}$ & Cream $=10$ \\
\hline Dry/chalk feel & A measure of powdery, dry sensation in the mouth. & $\begin{array}{l}\text { Inner surface of a banana peel }= \\
10\end{array}$ \\
\hline
\end{tabular}


Table 1: References and definitions for attributes developed in the descriptive sensory evaluation of low fat UHT milk in HDPE bottles. (Continued)

\begin{tabular}{|c|c|c|}
\hline Sensory attribute & Definition & Reference \\
\hline \multicolumn{3}{|l|}{ Flavour } \\
\hline Creamy flavour & $\begin{array}{l}\text { Intensity of cream flavour/ perceived creaminess of the } \\
\text { sample evaluated in the mouth. }\end{array}$ & Cream $=10$ \\
\hline Overall milk (dairy) flavour & $\begin{array}{l}\text { A general term describing the intensity of the aromatics } \\
\text { associated with products made from cow's milk. }\end{array}$ & Fresh cream $=10$ \\
\hline Sweet taste & $\begin{array}{l}\text { Fundamental taste association with the impression of all } \\
\text { sweet substances, e.g. sucrose }\end{array}$ & $10 \%$ Sucrose in water $=10$ \\
\hline $\begin{array}{l}\text { Off-flavour (Lack of } \\
\text { freshness) }\end{array}$ & $\begin{array}{l}\text { The extent to which the overall rounded dairy notes, } \\
\text { commonly associated with fresh milk are altered. A } \\
\text { combination of changes in amount or interactions of such } \\
\text { attributes as sweet, bitter, sour, dairy fat, butyric acid } \\
\text { and/or brown. }\end{array}$ & $\begin{array}{l}\text { Two day old unrefrigerated } \\
\text { pasteurized low fat milk }=10\end{array}$ \\
\hline \multicolumn{3}{|l|}{ Flavour } \\
\hline Cooked flavour & $\begin{array}{l}\text { The intensity of boiled milk flavour/ The combination of } \\
\text { brown flavour notes and aromatics associated with heated } \\
\text { milk. }\end{array}$ & $\begin{array}{l}\text { Heat fresh pasteurised milk to } \\
80^{\circ} \mathrm{C} \text { for } 1 \mathrm{~min}=2 \\
\text { Boil milk for } 3 \mathrm{~min}=8\end{array}$ \\
\hline \multicolumn{3}{|l|}{ Aftertaste } \\
\hline Fatty aftertaste & $\begin{array}{l}\text { The intensity of the oily feeling that remains in the } \\
\text { mouth after swallowing the sample }\end{array}$ & Cream $=10$ \\
\hline
\end{tabular}

Table 1: References and definitions for attributes developed in the descriptive sensory evaluation of low fat UHT milk in HDPE bottles. (Continued)

\begin{tabular}{lll}
\hline Sensory attribute & Definition & Reference \\
\hline Metallic & The intensity of the chemical feeling on the tongue & Copper 5c coins in milk overnight \\
& $\begin{array}{l}\text { described as flat. Associated with iron, copper and/or } \\
\text { silver spoons. }\end{array}$ \\
& Fundamental taste association with the impression of all & Sucrose in water $=10$ \\
\hline Sweet & sweet substances, e.g. sucrose & \\
& A measure of dry, powdery sensation that remains in the & Banana peel $=10$ \\
\hline Dry/chalk aftertaste & mouth after swallowing the sample &
\end{tabular}

each sample and was used for training and calibration of the descriptive panel over eight sessions. This method has been shown to optimize proficiency by ensuring efficient panel training and also reduces the training-time (Findlay, Castura, Schlich, \& Lesschaeve, 2006). The trained panellists evaluated the 18 attributes of maximum 9 randomly presented samples ( 3 samples per storage temperature) twice per week. The 
evaluation was performed by panellists seated at individual evaluation booths under daylight conditions (Osram, Lumilux De Luxe T8 daylight tubes) in the sensory laboratory of the University of Pretoria. Panellists rated the milk samples on a structured line scales with "not intense" on the one end and "extremely intense" on the other. Compusense Five version 5.2 software (Compusense Inc., Guelph, Canada) was used to generate all random codes, questionnaires and line scales used during screening, training and evaluation.

\subsection{Cut-off point determination using survival analysis}

Regular UHT milk consumers (120) were recruited and each consumer received 6 samples of low fat UHT milk that were stored at $45^{\circ} \mathrm{C}$ for different time periods (6, $12,18,24,30$ and 36 d) in random order. Reverse storage with a single low fat UHT milk batch was used. Milk was stored at $4^{\circ} \mathrm{C}$, where no significant changes in the sensory properties occurred as evaluated by the trained sensory panel during the test period. At time zero, 6 bottles of milk was placed at $45^{\circ} \mathrm{C}$, becoming the sample with the longest storage time. After $6 \mathrm{~d}$ the next sample was placed at $45^{\circ} \mathrm{C}$. This procedure was followed repeatedly to obtain samples with decreasing storage time at $45^{\circ} \mathrm{C}$. For evaluation by the consumers, the milk samples were prepared as described in Section 2.1. Consumers were asked to answer "yes" or "no" to the question "Would you normally consume this product?" if they had purchased the product or it was served to them in a home use situation. Filtered water was provided for neutralising and cleansing the palate before and between sample tasting. Compusense Five version 5.2 software (Compusense Inc., Guelph, Canada) was used to generate all random codes, questionnaires and to capture the consumers' responses.

\subsection{Nutritional and microbiological analyses of low fat UHT milk}

Freshly packed UHT milk samples were sent to a South African National Accreditation System laboratory, Lactolab (Agricultural Research Council campus, Irene, South Africa) where the gross composition (protein, lactose and fat content) and microbiological quality (coliforms, E. coli, spore formers and total counts) were determined. The spore formers and total counts of milk stored at room temperature were also evaluated once a month throughout the study. 


\subsection{Statistical data analysis}

\subsubsection{Microbiological and Nutritional data}

One-way Analysis of Variance (ANOVA) was performed to identify differences in the nutritional content and microbiological quality of different batches of freshly packed low fat UHT milk and also to identify any changes in the microbiological quality over time.

\subsubsection{Descriptive sensory analysis data}

Due to public holidays and some panellists falling ill, samples could not be tasted on all the anticipated days and/or panellists were unable to attend some of the tasting sessions, thus leading to unequally spaced time points and an incomplete data set. To deal with this problem, the descriptive sensory data was analysed using the mixed model procedure (PROC MIXED).The PROC MIXED procedure allows greater flexibility in modelling covariance structures for repeated measured data, and accounts for the within-subject time-dependent correlations (Littell, Milliken, Stroup, \& Wolfinger, 2006), while handling missing observations better in repeated measures data than conventional univariate and multivariate analysis of variance approaches. A model with an appropriate covariance structure for the within-subject correlation is essential to arrive at an accurate conclusion in a repeated measures analysis. For this study, as the time points (i.e. days) were unequally spaced two different covariance structures, i.e. compound symmetry (CS) and first-order ante dependence covariance ANTE(1), were considered for the analysis. A comparison of candidate models was achieved by running the PROC MIXED procedure with various covariance structures. The three information criteria provided by PROC MIXED, the Akaike Information Criteria (AIC), the finite-sample corrected Akaike Information Criteria (AICC) and the Schwarz's Bayesian Information Criteria (BIC) were used as a statistical tool to assist in model selection. The lowest value of information criterion is a better model fit to the data (SAS OnlineDoc®, Version 8, Cary, NC, USA: SAS Institute Inc., 1999). 


\subsubsection{Multivariate accelerated shelf-life test}

Repeated measure ANOVA was performed on the complete data set to determine which attributes showed significant changes over time. All the attributes that showed time related changes were then subjected to Principal Component Analysis (PCA) to allow a visual interpretation of the similarities and differences. The PC1 scores obtained from the PCA were further used in the multivariate accelerated shelf-life test (MASLT) method for shelf-life assessment by plotting these values against time. MASLT is based on compressing the space spanned by the original variables (sensory attributes) via PCA and then using the scores as properties for further shelf-life assessment (Pedro \& Ferreira, 2006).

The activation energy for the new multivariate data set was determined using the non-linear Arrhenius approach, which combines zero-order reaction rate (based on the results, it was the chosen order) with the Arrhenius model (Garitta, Hough, \& Sánchez, 2004; Gámbaro, Garitta, Giménez, Varela, \& Hough, 2004):

$$
A=A_{0}+k_{\text {ref }} \times t \times \exp \left(-\frac{E_{a}}{R}\left(\frac{1}{T}-\frac{1}{T_{\text {ref }}}\right)\right)
$$

Where, $A=$ multivariate data point / attribute at $t$;

$A_{0}=$ multivariate data point $/$ attribute at $t=0$;

$k_{\text {ref }}=$ reaction rate constant at $T_{\text {ref }}$;

$t=$ time

$E_{a}=$ activation energy;

$R=$ gas law constant;

$T=$ absolute temperature; and

$T_{\text {ref }}=$ reference temperature.

The linear regression facilities of $\mathrm{R}$ statistical software version 2.15.1 (The $\mathrm{R}$ Foundation for Statistical Computing, Vienna, Austria) were used to calculate the parameters of this model. The resulting activation energy was then further used to determine the acceleration factors at the various temperatures. The same model was used to determine the activation energy of the separate attributes. 


\subsubsection{Survival analysis}

Survival analysis methodology was used to determine the cut-off point for UHT milk stored at $45^{\circ} \mathrm{C}$, using the results obtained from consumers when asked if they would normally consume the samples with different storage times. A random variable $T$ can be defined as the storage time on which the consumer rejects the sample, but due to the consumers evaluating a limited number of samples with different storage times, the exact $T$ could not be observed, thus the censored nature of the data (Hough, Langohr, \& Gómez, 2003). When consumers are presented with samples stored at times $t 1, t 2$ and $t 3$ and a consumer rejects the sample at the first storage time, the point of rejection for that consumer is not observed since it is before the first storage time $(T \leq t 1)$ and the data are left censored. If the consumer accepts the sample stored for $t 1$ but rejects the sample stored for $t 2$, the exact time at which the consumer rejects the product occurs between $t 1$ and $t 2(t 1<T \leq t 2)$ and the data are interval censored. If, however, the consumer accepts all the samples, the point of rejection is after the last storage time observed $(T>t 3)$ and the data is right censored. The survival function $\mathrm{S}(t)$ can be defined as the probability of a consumer accepting a product stored for a time period longer than $t, \mathrm{~S}(t)=\mathrm{P}(T>t)$.

Parametric models were be used to obtain precise estimates of the survival function (Klein \& Moeschberger, 1997). Various distributions, including log-normal, Weibull, logistic, Gaussian, log logistic and exponential, were fitted to the data using $\mathrm{R}$ statistical software. The cut-off point of the low fat UHT milk stored at $45^{\circ} \mathrm{C}$ was estimated using a 50\% rejection level. Only data from consumers that did not reject the freshest sample $(6 \mathrm{~d})$ were included in the analysis, as per Hough, Garitta, and Gómez, (2006).

\section{RESULTS AND DISCUSSION}

\subsection{Milk composition and microbiological quality}

The freshly packed low fat UHT milk used during this study showed satisfactory milk composition and microbiological quality (Table 2). Smit and Schönfeldt (2006) 
reported the values for the fat, protein and lactose content of low fat UHT milk as $1.86 \%, 3.33 \%$ and $4.9 \%$, respectively. The nutritional values for the low fat UHT

Table 2: Milk composition and microbiological quality of freshly packed low fat UHT milk in HDPE bottles

\begin{tabular}{|c|c|c|c|}
\hline & Batch 1 & Batch 2 & Batch 3 \\
\hline \multicolumn{4}{|l|}{ Milk composition } \\
\hline$\%$ Fat $\left(\mathrm{g} .100 \mathrm{~g}^{-1}\right)$ & $1.62( \pm 0.01)^{\mathrm{a}}$ & $1.60( \pm 0.02)^{\mathrm{a}}$ & $1.57( \pm 0.00)^{\mathrm{a}}$ \\
\hline$\%$ Protein $\left(\mathrm{g} .100 \mathrm{~g}^{-1}\right)$ & $3.48( \pm 0.02)^{\mathrm{a}}$ & $3.48( \pm 0.01)^{\mathrm{a}}$ & $3.39( \pm 0.01)^{\mathrm{a}}$ \\
\hline$\%$ Lactose $\left(\mathrm{g} .100 \mathrm{~g}^{-1}\right)$ & $4.96( \pm 0.01)^{\mathrm{a}}$ & $4.91( \pm 0.02)^{\mathrm{a}}$ & $4.89( \pm 0.00)^{\mathrm{a}}$ \\
\hline \multicolumn{4}{|l|}{ Microbiological quality } \\
\hline E. coli $\mathrm{mL}^{-1}$ & $<1^{\mathrm{a}}$ & $<1^{\mathrm{a}}$ & $<1^{\mathrm{a}}$ \\
\hline Coliforms mL $\mathrm{mL}^{-1}$ & $<1^{\mathrm{a}}$ & $<1^{\mathrm{a}}$ & $<1^{\mathrm{a}}$ \\
\hline Total count $\mathrm{x} 1000 . \mathrm{mL}^{-1}$ & $<1^{\mathrm{a}}$ & $<1^{\mathrm{a}}$ & $<1^{\mathrm{a}}$ \\
\hline Aerobic spores. $\mathrm{mL}^{-1}$ & $<1^{\mathrm{a}}$ & $<1^{\mathrm{a}}$ & $<1^{\mathrm{a}}$ \\
\hline
\end{tabular}

*Values with same superscripts in rows represent no significant differences $(\mathrm{p}>0.05)$.

*Standard deviations shown in parenthesis.

Table 3: The effect of storage time on microbiological quality of low fat UHT milk in HDPE bottles.

\begin{tabular}{|c|c|c|c|c|c|c|c|}
\hline \multicolumn{8}{|c|}{ Microbiological analysis } \\
\hline Time (days) & $\mathbf{0}$ & 30 & 60 & 120 & 150 & 180 & 210 \\
\hline \multicolumn{8}{|c|}{ Total counts $\times 1000 . \mathrm{mL}^{-1}$} \\
\hline Batch 1 & $<1^{\mathrm{a}}$ & $<1^{\mathrm{a}}$ & $<1^{\mathrm{a}}$ & $<1^{\mathrm{a}}$ & $<1^{\mathrm{a}}$ & $<1^{\mathrm{a}}$ & $1^{a}$ \\
\hline Batch 2 & $<1^{\mathrm{a}}$ & $<1^{\mathrm{a}}$ & $<1^{\mathrm{a}}$ & $<1^{\mathrm{a}}$ & $<1^{\mathrm{a}}$ & $<1^{\mathrm{a}}$ & $<1^{\mathrm{a}}$ \\
\hline Batch 3 & $<1^{\mathrm{a}}$ & $<1^{\mathrm{a}}$ & $<1^{\mathrm{a}}$ & $<1^{\mathrm{a}}$ & $<1^{\mathrm{a}}$ & $<1^{\mathrm{a}}$ & $<1^{\mathrm{a}}$ \\
\hline \multicolumn{8}{|c|}{ Aerobic spores.mL $L^{-1}$} \\
\hline Batch 1 & $<1^{\mathrm{a}}$ & $<1^{\mathrm{a}}$ & $<1^{\mathrm{a}}$ & $<1^{\mathrm{a}}$ & $<1^{\mathrm{a}}$ & $<1^{\mathrm{a}}$ & $<1^{\mathrm{a}}$ \\
\hline Batch 2 & $<1^{\mathrm{a}}$ & $<1^{\mathrm{a}}$ & $<1^{\mathrm{a}}$ & $<1^{\mathrm{a}}$ & $<1^{\mathrm{a}}$ & $<1^{\mathrm{a}}$ & $<1^{\mathrm{a}}$ \\
\hline Batch 3 & $<1^{\mathrm{a}}$ & $<1^{\mathrm{a}}$ & $<1^{\mathrm{a}}$ & $<1^{\mathrm{a}}$ & $<1^{\mathrm{a}}$ & $<1^{\mathrm{a}}$ & $<1^{\mathrm{a}}$ \\
\hline
\end{tabular}

*Values with same superscripts in rows represent no significant differences $(\mathrm{p}>0.05)$.

milk correlate well with these values. Literature state that UHT processing renders milk bacteriologically stable at ambient temperatures for several months (Lewis \& Heppell, 2000; Valero et al., 2001). The microbiological quality of the freshly packed 
low fat UHT milk was very high with counts of $<1 \mathrm{~mL}^{-1} E$. coli, coliforms and spore formers and counts of $<1.1000 \mathrm{~mL}^{-1}$ for total counts. The microbiological quality was maintained throughout the duration of the study, showing no significant increase for either total counts or aerobic spores (Table 3). These results complied with the specifications of the South African Bureau of Standards that states that heattreated milk should not contain more than 50 colony forming units (cfu) per $\mathrm{mL}$ and should be free of any coliform bacteria, while UHT milk should be free of any bacteria.

Table 4: Model fit statistics ${ }^{1},-2 \times \log$ likelihood, Akaike Information Criteria (AIC), finite-sample corrected Akaike Information Criteria (AICC) and Schwarz's Bayesian Information Criteria (BIC), with two different covariance structures, compound symmetry (CS) and ante dependence (ANTE(1)), for the milk attributes.

\begin{tabular}{|c|c|c|c|}
\hline \multirow[t]{2}{*}{ Attribute } & \multirow[t]{2}{*}{ Fit statistics } & \multicolumn{2}{|c|}{ Covariance structure } \\
\hline & & $\mathrm{CS}$ & ANTE(1) \\
\hline \multirow[t]{4}{*}{ Overall milk aroma intensity } & $-2 \times$ Log likelihood & 1291.7 & 1054.8 \\
\hline & AIC & 1295.7 & 1156.8 \\
\hline & AICC & 1295.7 & 1159.6 \\
\hline & $\mathrm{BIC}$ & 1300.9 & 1289.2 \\
\hline \multirow[t]{4}{*}{ Fresh milk aroma intensity } & $-2 \times$ Log likelihood & 2291.1 & 1987.4 \\
\hline & AIC & 2295.1 & 2089.4 \\
\hline & AICC & 2295.1 & 2092.2 \\
\hline & BIC & 2300.2 & 2221.7 \\
\hline \multirow[t]{4}{*}{ Cooked aroma } & $-2 \times$ Log likelihood & 1581.3 & 1326.1 \\
\hline & AIC & 1585.3 & 1428.1 \\
\hline & AICC & 1585.3 & 1430.9 \\
\hline & $\mathrm{BIC}$ & 1590.5 & 1560.4 \\
\hline \multirow[t]{4}{*}{ Glass coating } & $-2 \times$ Log likelihood & -182.5 & -416.4 \\
\hline & $\mathrm{AIC}$ & -178.5 & -314.4 \\
\hline & AICC & -178.5 & -331.6 \\
\hline & $\mathrm{BIC}$ & -173.4 & -182.0 \\
\hline \multirow[t]{4}{*}{ Extent of visual thickness } & $-2 \times$ Log likelihood & 456.2 & 209.6 \\
\hline & AIC & 460.3 & 311.6 \\
\hline & AICC & 460.3 & 314.4 \\
\hline & $\mathrm{BIC}$ & 465.3 & 443.9 \\
\hline \multirow[t]{3}{*}{ Viscosity } & $-2 \times$ Log likelihood & 771.3 & 520.8 \\
\hline & AIC & 775.3 & 622.8 \\
\hline & AICC & 775.3 & 625.6 \\
\hline
\end{tabular}


Table 4: Model fit statistics ${ }^{1},-2 \times \log$ likelihood, Akaike Information Criteria (AIC), finite-sample corrected Akaike Information Criteria (AICC) and Schwarz's Bayesian Information Criteria (BIC), with two different covariance structures, compound symmetry (CS) and ante dependence (ANTE(1)), for the milk attributes (Continued).

\begin{tabular}{|c|c|c|c|}
\hline \multirow[t]{2}{*}{ Attribute } & \multirow[t]{2}{*}{ Fit statistics } & \multicolumn{2}{|c|}{ Covariance structure } \\
\hline & & $\mathrm{CS}$ & ANTE(1) \\
\hline \multirow[t]{4}{*}{ Fat feel } & $-2 \times$ Log likelihood & 1256.5 & 1020.8 \\
\hline & AIC & 1260.6 & 1122.8 \\
\hline & AICC & 1260.6 & 1125.6 \\
\hline & BIC & 1275.6 & 1255.2 \\
\hline \multirow[t]{4}{*}{ Mount coating } & $-2 \times$ Log likelihood & 999.5 & 758.3 \\
\hline & AIC & 1003.5 & 860.3 \\
\hline & AICC & 1003.5 & 863.1 \\
\hline & BIC & 1008.7 & 992.7 \\
\hline \multirow[t]{4}{*}{ Dry/chalk feel } & $-2 \times$ Log likelihood & 197.3 & 239.8 \\
\hline & AIC & 201.3 & 340.8 \\
\hline & $\mathrm{AICC}$ & 201.4 & 343.6 \\
\hline & BIC & 206.5 & 473.2 \\
\hline \multirow[t]{4}{*}{ Overall milk flavour } & $-2 \times$ Log likelihood & 2412.4 & 2125.6 \\
\hline & AIC & 2416.4 & 2227.6 \\
\hline & AICC & 2416.4 & 2230.4 \\
\hline & $\mathrm{BIC}$ & 2421.5 & 2359.9 \\
\hline \multirow[t]{4}{*}{ Creamy flavour } & $-2 \times$ Log likelihood & 1331.7 & 1024.7 \\
\hline & AIC & 1335.7 & 1126.7 \\
\hline & AICC & 1335.8 & 1129.5 \\
\hline & BIC & 1340.9 & 1259.0 \\
\hline \multirow[t]{4}{*}{ Cooked flavour } & $-2 \times$ Log likelihood & 1431.3 & 1176.1 \\
\hline & AIC & 1435.3 & 1278.1 \\
\hline & AICC & 1435.3 & 1280.9 \\
\hline & BIC & 1440.5 & 1410.4 \\
\hline
\end{tabular}


To deal with the missing data, two models were considered, i.e. ANTE(1) and CS, and the one that best fit the data was chosen for each of the attributes (Table 4). The model with the lowest value of information criteria, i.e. log likelihood, AIC, AICC and BIC, was the best fit to the data (SAS Institute, Inc. 1999). CS was chosen for the following sensory attributes; dry/chalk feel, off-flavour (lack of freshness), sweet taste, dry chalk aftertaste, metallic aftertaste and sweet aftertaste, while ANTE(1) was chosen for the overall milk aroma intensity, fresh milk aroma intensity, cooked aroma, glass coating, extent of visual thickness, viscosity, fat feel, mouth coating, overall milk flavour, cooked flavour, creamy flavour and fatty aftertaste.

PCA was performed on all the data that showed significant changes over time. Cooked aroma, glass coating, viscosity, fat feel, mouth coating and fatty aftertaste did not present significant changes and were excluded from the PCA. Fig. 1 summarizes the sensory profiling results and explains in one plot the differences and similarities between the various milk samples stored at the different temperatures and time periods. Note that the milk samples stored at 35 and $45{ }^{\circ} \mathrm{C}$ were evaluated by the sensory panel only until day 176 and 78, respectively. By these time periods, the UHT milk already showed advance signs of deterioration, including discolouration, high acid degree, separation and low $\mathrm{pH}$ values.

In the PCA (Fig. 1a), Factor 1 explains $73.1 \%$ of the variation in the sensory profiles of the milk samples. It separates milk samples on the right of the plot i.e. freshly packed UHT milk samples and milk stored at $25^{\circ} \mathrm{C}$, which had a more intense sweet taste and aftertaste, fresh milk aroma intensity, creamy flavour, extent of visual thickness and overall milk flavour, from those on the left. The latter samples, notably the UHT milk stored at higher temperatures and for longer time periods had a higher intensity of dry/chalk feel and aftertaste, off-flavour (lack of freshness), metallic flavour and aftertaste and cooked flavour.

Factor 2, separating samples at the top of the plot from those at the bottom of the plot, explains an additional $10.7 \%$ of the sensory variation of the milk samples. This second plane mainly describes milk with a more intense overall milk aroma at the bottom. Samples at the bottom of the plot (fresher samples) had higher overall milk 
a i)

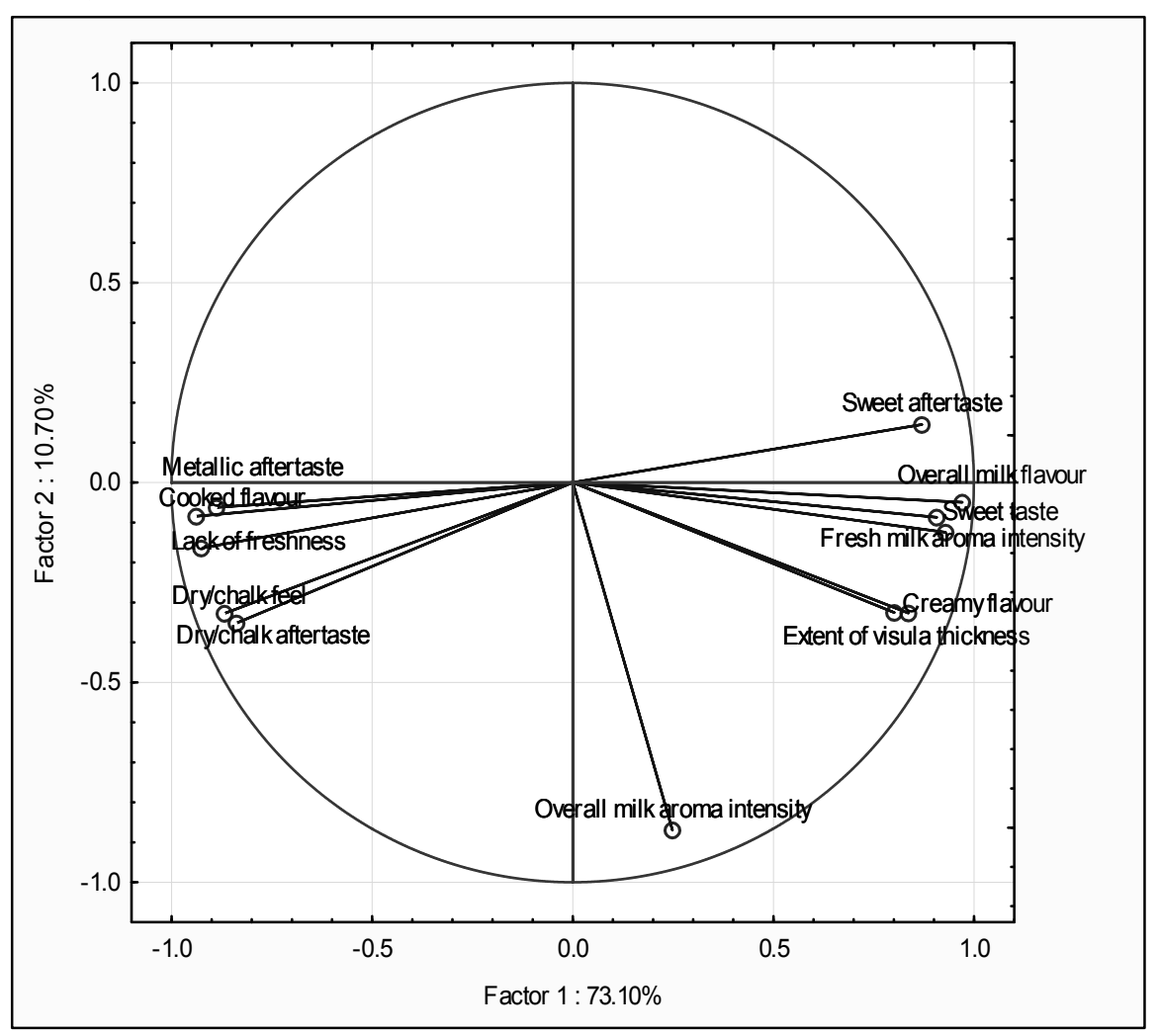

ii)

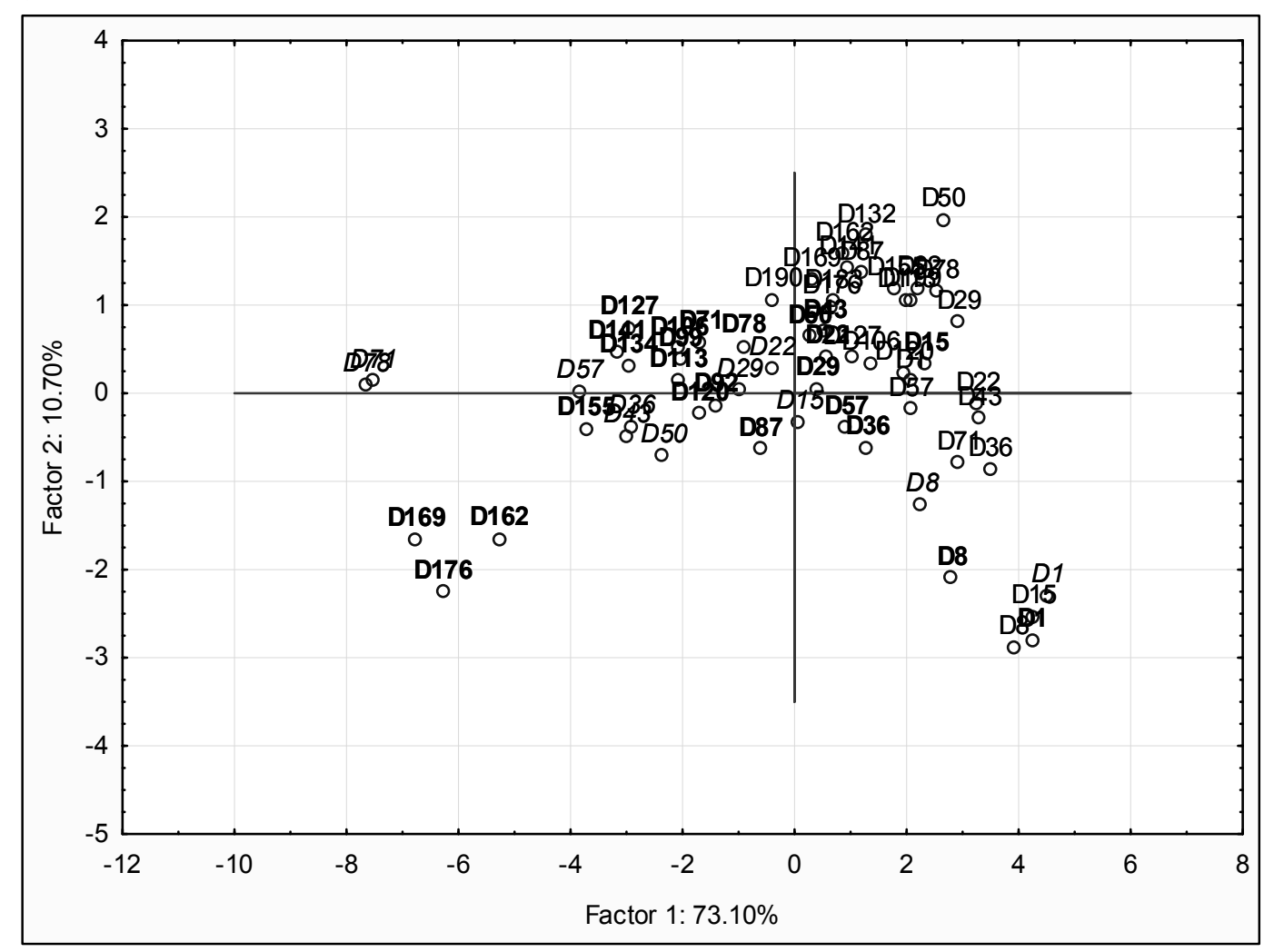



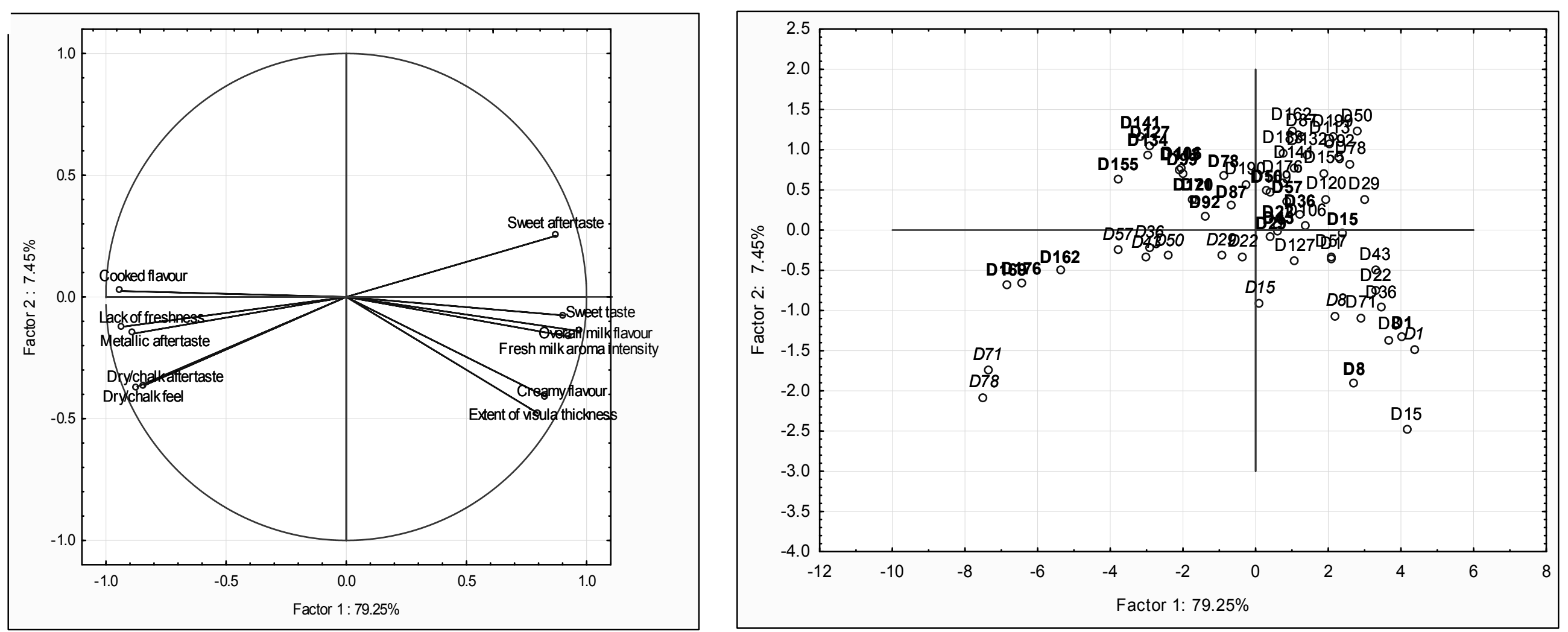

Figure 1a \& b: Principal component analysis of low fat UHT milk in HDPE bottles stored at different temperatures $\left(25^{\circ} \mathrm{C}, 35^{\circ} \mathrm{C} 45^{\circ} \mathrm{C}\right)$ of different days $\mathrm{D}$ (D1-D192 for milk stored at $25^{\circ} \mathrm{C}$, D1-D176 for milk stored at $35^{\circ} \mathrm{C}$ and $D 1-D 78$ for milk stored at $45^{\circ} \mathrm{C}$ ) as profiled by the trained sensory panel $(\mathrm{i}=$ scores for the sensory attributes and $\mathrm{ii}=$ the correlation loadings for the milk samples stored at different temperatures over time). 

aroma intensities than those at the top of the plot. This attribute contributed very little to PC1 as compared to the other attributes and most of the information brought by this PC is related to noise and can be therefore be excluded from the MASLT.

A new PCA was performed on all the attributes that contributed to PC1 (Fig. 1b), i.e. all the attributes used in the first PCA except overall milk aroma, and the scores from this PCA were then further used in the MASLT. In this PCA, Factor 1 explains more than $79 \%$ of the variation in the sensory profiles of the milk and sample separation was similar to the previous PCA.

Shelf-life studies require the identification of a critical attribute, i.e. the attribute that has the highest impact on the quality of the milk, or shows the most change over the shortest time period. This is a very hard decision to make, especially when sensory variables are included in the study (Curia \& Hough, 2009; Hough et al., 2002; Martínez, Mucci, Santa Cruz, Hough, \& Sanchez, 1998). The multivariate accelerated shelf-life approach includes all the attributes that show change over time and gives a single acceleration coefficient (Labuza \& Schmidl, 1985; Pedro \& Ferreira, 2006). Figure 2 shows the PC1 scores versus time chart together with the regression curves. It clearly shows that $\mathrm{PCl}$ is time-structured, making it suitable for estimating the shelf-life parameters.

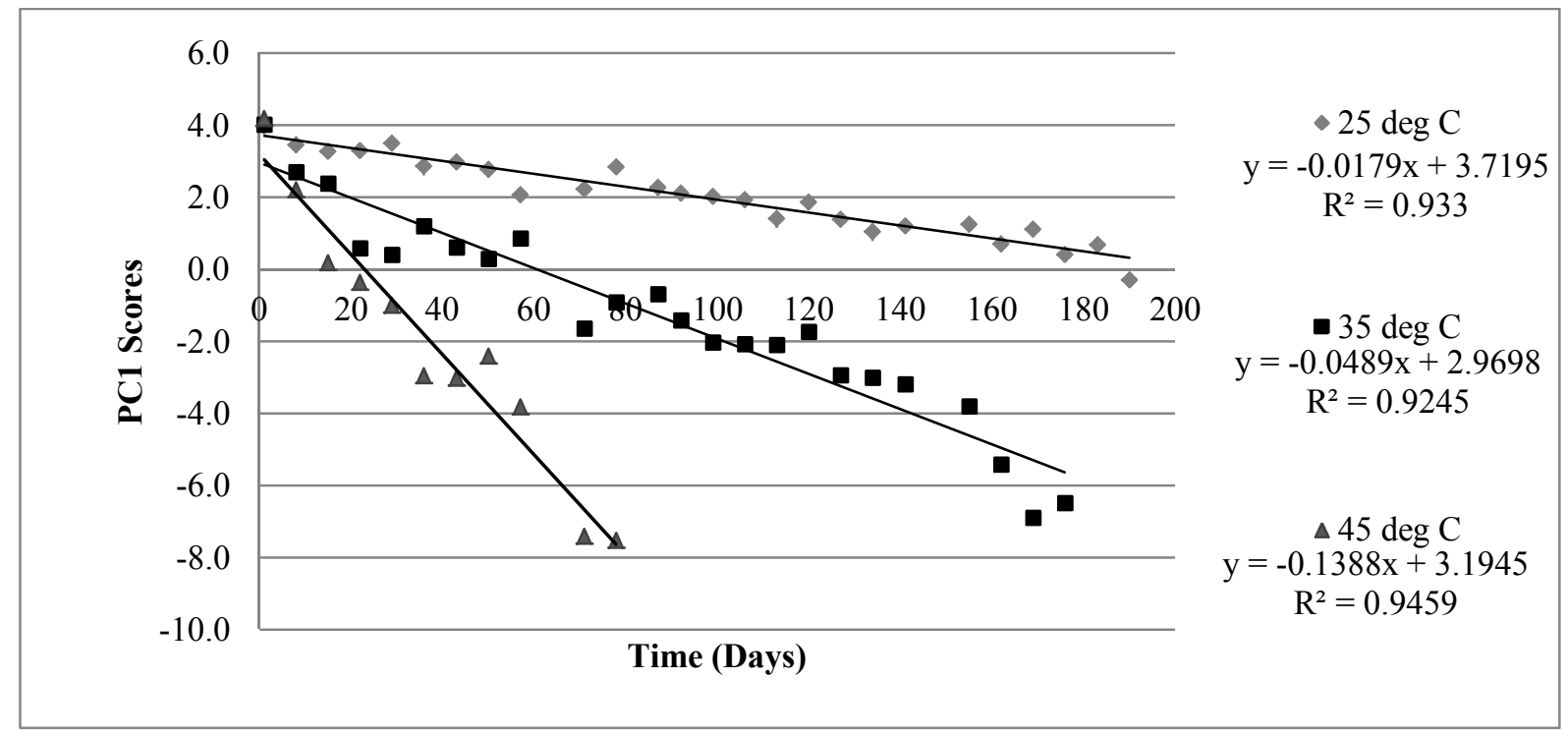

Figure 2: Multivariate kinetic chart of low fat UHT milk in HDPE bottles stored at 25, 35 and $45^{\circ} \mathrm{C}$. 
Table 5: Log-likelihood values for different distributions fitted to the survival analysis data. The model with the lowest log-likelihood value shows the best adjustment to the data.

\begin{tabular}{ll}
\hline Model & Log-likelihood \\
\hline Weibull & 126.1835 \\
Logistic & 126.2498 \\
Gaussian & 126.4635 \\
Log-logistic & 127.2732 \\
Log-normal & 128.1593 \\
Exponential & 153.8559 \\
\hline
\end{tabular}


To determine the end of shelf-life, survival analysis was used to determine the cut-off point. For the survival analysis data, the following standard distributions were compared: Weibull, logistic, Gaussian, log-logistic, log-normal and exponential (Table 5). Survival analysis of the data showed that the Weibull, logistic and Gaussian distributions all fitted the shelf-life data well when the lowest absolute log-likelihood value was taken as criteria in choosing between the distributions (Hough, 2010). Based on this criterion, the Weibull distribution adjusted best to the data. In addition to this, the Weibull distribution is the most commonly used distribution based on the flexibility, simplicity and good fit to survival data (Calligaris, Manzocco, Kravina, \& Nicoli, 2007; Guerra, Lagazio, Manzocco, Barnaba, \& Cappuccio, 2008; Hough et al., 2003; Curia, Aguerrido, Langohr, \& Hough, 2005) and was chosen to model the rejection of low fat UHT milk stored at $45^{\circ} \mathrm{C}$ (Fig. 3).

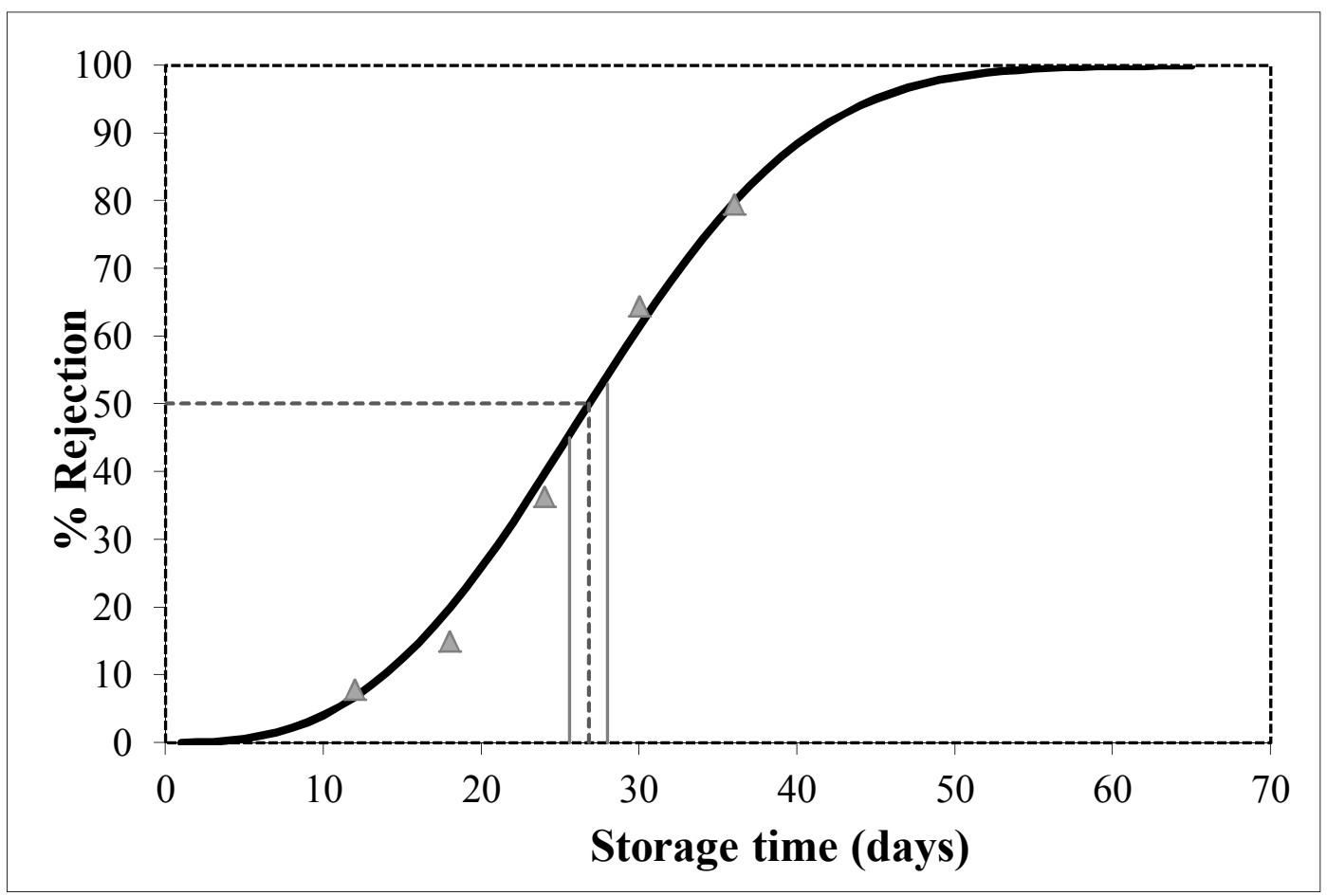

Figure 3: Percentage of consumers rejecting the product versus storage time. $50 \%$ rejection points $=$ dotted line, $95 \%$ confidence intervals $=$ grey solid lines, nonparametric data points $=$ triangles.

To determine the shelf-life of the low fat UHT milk, the probability of a consumer rejecting the product was chosen at $50 \%$ for milk stored at $45^{\circ} \mathrm{C}$ and this was used as the cut-off point, i.e. the maximum level of the attributes. This level of rejection has been used in various studies, including shelf-life studies of yoghurt (Curia et al., 2005), coffee (Cardelli and Labuza, 2001) and minced meat (Hough et al., 2006). 
With the end of shelf-life set at the point where $50 \%$ of the consumers who had accepted the freshest sample rejected the product, the Weibull distribution (Fig. 5) gave a predicted end of shelf-life storage time of $27( \pm 1) \mathrm{d}$ and a resulting cut-off point of -0.532 (PC1 score).

Table 6: Multivariate parameters for low fat UHT milk

\begin{tabular}{|c|c|c|c|c|c|}
\hline \multirow[t]{2}{*}{$\begin{array}{l}\text { Temperature } \\
{ }^{\circ} \mathrm{C}\end{array}$} & \multirow[t]{2}{*}{$\begin{array}{l}\text { Rate constant }(k) \\
\text { PC score.day }\end{array}$} & \multirow[t]{2}{*}{$\begin{array}{l}\text { Activation energy } \\
\left(\mathrm{E}_{\mathrm{a}}\right) \mathbf{k J . m o l}{ }^{-1}\end{array}$} & \multirow{2}{*}{$\begin{array}{l}\text { Coefficient of } \\
\text { determination } \\
\left(\mathbf{R}^{2}\right)\end{array}$} & \multicolumn{2}{|c|}{$\begin{array}{l}\text { Acceleration factor } \\
(\alpha)\end{array}$} \\
\hline & & & & $\alpha_{35,25}$ & $\alpha_{45,35}$ \\
\hline $25^{\circ} \mathrm{C}$ & -0.0179 & 19.2964 & 0.9330 & 2.8934 & 2.7136 \\
\hline $35^{\circ} \mathrm{C}$ & -0.0489 & & 0.9245 & & \\
\hline $45^{\circ} \mathrm{C}$ & -0.1395 & & 0.9459 & & \\
\hline
\end{tabular}

Using the multivariate parameters calculated using non-linear regression (Table 6), the shelf-life of the low fat UHT milk stored at 35 and $25^{\circ} \mathrm{C}$ was estimated at $73( \pm 3)$ and $211( \pm 7) \mathrm{d}$, respectively. The multivariate acceleration factor, also known as $\mathrm{Q}_{10}$ value when there are $10^{\circ} \mathrm{C}$ increments, was determined to be 2.89 and 2.71 when the storage temperatures increased from 25 to $35^{\circ} \mathrm{C}$ and from 35 to $45^{\circ} \mathrm{C}$, respectively. Therefore, the rate of sensory deterioration of the milk at $35^{\circ} \mathrm{C}$ will be more than 2.89 times faster, and the rate at $45^{\circ} \mathrm{C}$ will be 7.83 times faster, than the rate at $25^{\circ} \mathrm{C}$. This means that, for an estimated shelf-life of $211 \mathrm{~d}$, future MASLT have to be conducted for $73 \mathrm{~d}$ at $35^{\circ} \mathrm{C}$ or only $27 \mathrm{~d}$ at $45^{\circ} \mathrm{C}$.

When the activation energies for all the attributes were calculated (Table 7), the fresh milk aroma intensity, cooked flavour and off-flavour (lack of freshness) had activation energies of $19.08,19.31$ and $18.99 \mathrm{~kJ}^{-\mathrm{mol}^{-1}}$, respectively, all of which are very similar to that of the multivariate results $\left(19.30 \mathrm{~kJ} \mathrm{~mol}^{-1}\right)$ of the UHT milk. The acceleration factors for fresh milk aroma intensity, cooked flavour and off-flavour were $2.74,2.94$ and 2.85 , respectively, when the temperature was increased from 25 to $35^{\circ} \mathrm{C}$, while it was $2.85,2.71$ and 2.68 , respectively, when the temperature was increased from 35 to $45^{\circ} \mathrm{C}$. These values are also very similar to those of the multivariate results and changes over time and temperatures for these attributes will therefore correlate well with those of the multivariate parameters. This makes all 
Table 7: Parameters of the sensory attributes of low fat UHT milk.

\begin{tabular}{|c|c|c|c|c|c|c|}
\hline \multirow[t]{2}{*}{ Attribute } & \multirow[t]{2}{*}{ Kinetic order $n$} & \multirow[t]{2}{*}{ Temperature $\left({ }^{\circ} \mathrm{C}\right)$} & \multirow{2}{*}{$\begin{array}{l}\text { Rate constant } k \\
\left(\text { PC score.day }{ }^{-1}\right)\end{array}$} & \multicolumn{2}{|c|}{ Acceleration factor } & \multirow{2}{*}{ 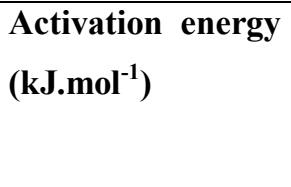 } \\
\hline & & & & $\alpha_{35,25}$ & $\alpha_{45,35}$ & \\
\hline \multirow{3}{*}{$\begin{array}{l}\text { Fresh milk aroma } \\
\text { intensity }\end{array}$} & Zero & 25 & -0.0015 & 2.7404 & 2.8505 & $19.0801 \quad( \pm 2.5683)$ \\
\hline & & 35 & -0.0042 & & & \\
\hline & & 45 & -0.0113 & & & \\
\hline \multirow{3}{*}{$\begin{array}{l}\text { Extent of visual } \\
\text { thickness }\end{array}$} & Zero & 25 & -0.0015 & 1.5448 & 1.5031 & 7.9042 \\
\hline & & 35 & -0.0019 & & & $( \pm 2.3739)$ \\
\hline & & 45 & -0.0035 & & & \\
\hline \multirow[t]{3}{*}{ Dry/chalk feel } & Zero & 25 & 0.0031 & 3.2107 & 2.9834 & 20.8779 \\
\hline & & 35 & 0.0143 & & & $( \pm 3.0672)$ \\
\hline & & 45 & 0.0289 & & & \\
\hline \multirow[t]{3}{*}{ Cooked flavour } & Zero & 25 & 0.0054 & 2.9357 & 2.7065 & 19.3089 \\
\hline & & 35 & 0.0169 & & & $( \pm 5.4601)$ \\
\hline & & 45 & 0.0404 & & & \\
\hline \multirow[t]{3}{*}{ Overall milk flavour } & Zero & 25 & $\begin{array}{l}-0.0024 \\
\end{array}$ & 2.4141 & 2.2839 & 16.0162 \\
\hline & & 35 & -0.0057 & & & $( \pm 3.0869)$ \\
\hline & & 45 & -0.0130 & & & \\
\hline \multirow[t]{3}{*}{ Creamy flavour } & Zero & 25 & -0.0016 & 1.9022 & 1.8268 & 11.6855 \\
\hline & & 35 & -0.0025 & & & $( \pm 4.2451)$ \\
\hline & & 45 & -0.0057 & & & \\
\hline
\end{tabular}

Table 7: Parameters of the sensory attributes of low fat UHT milk (Continued). 


\begin{tabular}{|c|c|c|c|c|c|c|}
\hline \multirow[t]{2}{*}{ Attribute } & \multirow[t]{2}{*}{ Kinetic order $n$} & \multirow[t]{2}{*}{ Temperature $\left({ }^{\circ} \mathrm{C}\right)$} & \multirow{2}{*}{$\begin{array}{l}\text { Rate constant } k \\
\left(\text { PC score.day }{ }^{-1}\right)\end{array}$} & \multicolumn{2}{|c|}{ Acceleration factor } & \multirow{2}{*}{$\begin{array}{l}\text { Activation energy } \\
\left({\left.\mathrm{kJ} . \mathrm{mol}^{-1}\right)}^{-1}\right.\end{array}$} \\
\hline & & & & $\alpha_{35,25}$ & $\alpha_{45,35}$ & \\
\hline \multirow{4}{*}{$\begin{array}{l}\text { Off-flavour (Lack of } \\
\text { freshness) }\end{array}$} & Zero & 25 & 0.0011 & 2.852858 & 2.68497 & 18.9871 \\
\hline & & & & & & $( \pm 2.7423)$ \\
\hline & & 35 & 0.0034 & & & \\
\hline & & 45 & 0.0074 & & & \\
\hline \multirow[t]{3}{*}{ Sweet taste } & Zero & 25 & -0.0005 & 3.7506 & 3.4513 & 24.0236 \\
\hline & & 35 & -0.0012 & & & $( \pm 5.5764)$ \\
\hline & & 45 & -0.0033 & & & \\
\hline \multirow[t]{3}{*}{ Dry/chalk aftertaste } & Zero & 25 & 0.0013 & 3.0258 & 2.8718 & 20.4585 \\
\hline & & 35 & 0.0086 & & & $( \pm 6.4902)$ \\
\hline & & 45 & 0.0143 & & & \\
\hline \multirow[t]{3}{*}{ Metallic aftertaste } & Zero & 25 & 0.0061 & 1.6098 & 1.5623 & 8.6522 \\
\hline & & 35 & 0.0113 & & & $( \pm 1.2624)$ \\
\hline & & 45 & 0.0258 & & & \\
\hline \multirow[t]{3}{*}{ Sweet aftertaste } & Zero & 25 & 0.0040 & 2.6763 & 2.5156 & 17.8076 \\
\hline & & 35 & 0.0081 & & & $( \pm 4.2375)$ \\
\hline & & 45 & 0.0251 & & & \\
\hline
\end{tabular}


these attributes good candidates for predictors of end of shelf-life and can also minimise the number of attributes to be assessed in future studies.

\section{CONCLUSION}

The multivariate accelerated shelf-life test was successfully applied to the low fat UHT milk and the shelf-life of the designated low fat UHT milk in HDPE bottles was estimated to be $211( \pm 7) \mathrm{d}$ when stored at optimum conditions of $25^{\circ} \mathrm{C}$. Higher temperatures of storage negatively affected the shelf-life of the milk and shelflife was shortened to $73( \pm 3)$ and $27( \pm 1)$ d when stored at accelerated temperatures of $35^{\circ} \mathrm{C}$ and $45^{\circ} \mathrm{C}$, respectively. Storage at $35^{\circ} \mathrm{C}$ and $45^{\circ} \mathrm{C}$ reduced the shelf-life by a factor of 2.9 and 2.7 , respectively, for every $10^{\circ} \mathrm{C}$ increase in storage temperature. The activation energies and acceleration factors of the fresh milk aroma intensity, cooked flavour and off-flavour (lack of freshness) correlated the best with those of the multivariate data. In future, these attributes can be used as predictors for the end of shelf-life for low fat UHT milk in HDPE bottles.

\section{REFERENCES}

Bassette, R., Fung, D. Y. C., \& Mantha, V.R. (1986). Off-flavours in milk. CRC Critical Review in Food Science and Nutrition, 24, 1-5.

Borle, F., Sieber, R., \& Bosset, J.O. (2001). Photo-oxidation and photoprotection of foods, with particular reference to dairy products: An update of a review article. Sciences des Aliments, 21, 571-590.

Burton, H. (1988). Ultra-high-temperature processing of milk and milk products. New York, NY, USA: Elsevier Applied Science Publications.

Calligaris, S., Manzocco, L., Kravina, G., \& Nicoli, C.M. (2007). Shelf-life modelling of bakery products by using oxidation indices. Journal of Agriculture and Food Chemistry, 55, 2004-2009. 
Cardelli, C., \& Labuza, T.P. (2001). Application of Weibull hazard analysis to the determination of the shelf-life of roasted and ground coffee. Lebensmittel-Wissenschaft Technology, 34, 273-278.

Chapman, K.W., Lawless, H.T., \& Boor, K.J. (2001). Quantitative descriptive analysis and principal component analysis for sensory characterization of ultra pasteurized milk. Journal of Dairy Science, 84, 12-20.

Chen, L., Daniel, R. M., \& Coolbear, T. (2003). Detection and impact of protease and lipase activities in milk and milk powders. International Dairy Journal, 13, 255275.

Claassen, M., \& Lawless, H.T. (1992). Comparison of descriptive terminology system for sensory evaluation of fluid milk. Journal of Food Science, 57, 596-600.

Corrigan, V., Hedderley, D., \& Harvey, W. (2012). Modeling the shelf-life of fruitfilled snack bars using survival analysis and sensory profiling techniques. Journal of Sensory studies, 27, 403-416.

Curia, A., Aguerrido, M., Langohr, K., \& Hough, G. (2005). Survival analysis applied to sensory shelf-life of yogurts, I. Argentine formulations. Journal of Food Science, $70,442-445$.

Curia, A.V., \& Hough, G.E. (2009). Selection of a sensory marker to predict the sensory life of a fluid human milk replacement formula. Journal of Food Quality, 32, 793-809.

Datta, N., \& Deeth, H. C. (2003). Diagnosing the cause of proteolysis in UHT milk. Food Science and Technology, 36, 173-182.

Deeth, H. C., \& Fitz-Gerald, C. H. (1983). Lipolytic enzymes and hydrolytic rancidity in milk and milk products. In P. F. Fox (Ed.), Developments in dairy chemistry, Part II, (pp. 195-239). London, UK: Applied Science.

Deeth, H.C., \& Fitz-Gerald, C.H. (1994). Lipolytic enzymes and hydrolytic rancidity in milkand milkproducts. In P. F. Fox (Ed.), Advanced dairy chemistry, Vol. 2: Lipids. (pp. 247-308). London: Chapman \& Hall. 
Findlay, C.J., Castira, J.C., Schlich, P., \& Lesschaeve, I. (2006). Use of feedback calibration to reduce the training time for wine panels. Food Quality and Preference, 17, $266-276$.

Frandsen, L.W., Dijksterhuis, G., Brockhoff, P., Nielsen, J.H., \& Martens, M. (2003). Subtle differences in milk, comparison of an analytical and an affective test. Food Quality and Preference, 14, 515-526.

Frost, M.B., Dijksterhuis, G., \& Martens, M. (2001). Sensory perception of fat in milk. Food Quality Preference, 12, 327-336.

Gámbaro, A., Garitta, L., Giménez, A., Varela, P., \& Hough, G. (2004). Sensory shelf-life estimation of "alfajor" by survival analysis. Journal of Sensory Studies, 19, 500-509.

Garitta, L., Hough, G., \& Sánchez, R. (2004). Sensory shelf-life of dulce de leche. Journal of Dairy Science, 87, 1601-1607.

Gebre-Egziabher, A., Humbert, E.S., \& Blankenagel, G. (1980). Hydrolysis of milk proteins by microbial enzymes. Journal of Food Protection, 43, 709-712.

Grunert, K.G. (2005). Food quality and safety, consumer perception and demand. European Review of Agricultural Economics, 32, 369-391.

Guerra, S., Lagazio, C., Manzocco, L., Barnaba, M., \& Cappuccio, R. (2008). Risks and pitfalls of sensory data analysis for shelf-life prediction, Data simulation applied to the case of coffee. LWT-Food Science and Technology, 41, 2070-2078.

Hedegaard, R.V., Kristensen, D., Nielsen, J.H., Frøst, M.B., Østdal, H., Hermansen, J.E., Kröger-Ohlsen, M., \& Skibsted, L.H. (2006). Comparison of descriptive sensory analysis and chemical analysis for oxidative changes in milk. Journal of Dairy Science, 89, 495-504.

Hough, G., Sanchez, R.H., Garbarini de Pable, G., Sánchez, R.G., Calderón Villaplana, S., Giménez, A.M., \& Gámbaro, A. (2002). Consumer acceptability versus trained sensory panel scores of powdered milk shelf-life defects. Journal of Dairy Science, 85, 2075-2080. 
Hough, G., Langhour, K., Gómez, G., \& Curia, A. (2003). Survival analysis applied to sensory shelf-life of foods. Journal of Food Science, 68, 359-362.

Hough, G., Garitta, L., \& Gómez, G. (2006). Sensory shelf-life predictions by survival analysis accelerated storage models. Food Quality and Preference, 17, 468473.

Hough, G. 2010. Sensory shelf-life estimation of food products. London, UK: CRC Press Inc.

Hugas, M., Garriga, M., \& Monfort, J.M. (2002). New mild technologies in meat processing, high pressure as a model technology. Meat Science, 62, 359-371

Klein, J. P., \& Moeschberger, M. L. (1997). Survival analysis, a self-learning text. New York, NY, USA: Springer-Verlag.

Labuza, T.P., \& Schmidl, M.K. (1985). Accelerated shelf-life testing of foods. Food Technology, 39, 57-64.

Lewis, M.J., \& Heppell, N. (2000). Continuous thermal processing of foods, Pasteurization and UHT sterilization. Gaitersburg, MD, USA: Aspen Publishers.

Littell, R.C, Milliken, G A., Stroup, W.W., \& Wolfinger, R.D. (2006). SAS System for Mixed Models (second edition), Cary, NC, USA: SAS Institute Inc.

McMahon, D. J. (1996). Age-gelation of UHT milk: Changes that occur during storage, their effect on shelf life and the mechanism by which age-gelation occurs. In IDF Symposium, Vienna, Heat treatments and alternative methods (pp. 315-326). Brussels, Belgium: International Dairy Federation.

Martínez, C.A., Mucci, C., Santa Cruz, M.J., Hough, G., \& Sanchez, R. (1998). Influence of temperature, fat content and package material on the sensory shelf life of commercial mayonnaise. Journal of Sensory Studies, 13, 331-346.

Meeker, W.Q., \& Escobar, L.A. (1998). Statistical methods for reliability data. New York, NY, USA: John Wiley \& Sons. 
Pedro, A.M.K., \& Ferreira, M.M.C. (2006). Multivariate accelerated shelf-life testing, A novel approach for determining the shelf-life of foods. Journal of Chemometrics, 20, 76-83.

Perkins, M.L., D’Arcy, B.R., Lisle, A.T., \& Deeth, H.C. (2005). Solid phase microextraction of stale flavour volatiles from the headspace of UHT milk. Journal of the Science of Food and Agriculture, 85, 2421-2428.

SAN ISO/IEC.4832. (2006). Microbiology of Food and Animal Feeding Stuff. Pretoria, South Africa: South African Bureau of Standards.

Smith, D., \& Sparks, L. (2004). Temperature Controlled Supply Chains. In M.A. Bourlakis, \& P.W.H. Weightman (Eds.), Food Supply Chain Management (pp. 179198). Oxford, UK: Blackwell Publishing Ltd.

Smit, L.E., \& Schönfeldt, H.C. (2006). The nutritional content of South African milk and liquid milk products. Part 2. Dairy Industry Centre, Irene, South Africa: ARCAnimal Nutrition and Animal Products Institute.

Valero, E., Villamiel, M., Miralles, B., Sanz, J., \& Martínez-Castro, I. (2001).

Changes in flavour and volatile components during storage of whole and skimmed UHT milk. Food Chemistry, 72, 51-58.

Williams, E.J. (1949). Experimental designs balanced for the estimation of residual effects of treatments. Australian Journal of Scientific Research, 2, 149-168. 